\title{
pH Influence on Antibacterial Efficacy of Common Antiseptic Substances
}

\author{
Cornelia Wiegand $^{\mathrm{a}}$ Martin Abel $^{\mathrm{b}}$ Peter Ruth ${ }^{\mathrm{c}}$ Peter Elsner ${ }^{\mathrm{a}}$ \\ Uta-Christina Hipler ${ }^{\text {a }}$ \\ a Department of Dermatology, University Hospital Center Jena, Jena, ${ }^{\mathrm{b}}$ Lohmann \& Rauscher GmbH \& Co. KG, \\ Rengsdorf, and ' Lohmann \& Rauscher GmbH \& Co. KG, Neuwied, Germany
}

\section{Key Words}

Antiseptic · Chronic wound $\cdot \mathrm{pH} \cdot$ Pseudomonas aeruginosa . Staphylococcus aureus

\begin{abstract}
Background: Wound infection plays an important role in compromised wound healing. A high bioburden impairs healing and leads to formation of a chronic wound. Distinctly higher $\mathrm{pH}$ values were observed in chronic wounds compared to acute wounds. However, there is only limited knowledge of $\mathrm{pH}$ dependency on the antibacterial efficacy of common antimicrobial substances. Methods: This study investigated the $\mathrm{pH}$ influence on the antimicrobial efficacy of povidone (PVP)-iodine, silver nitrate, chlorhexidine, octenidine and polihexanide against Staphylococcus aureus and Pseudomonas aeruginosa using the agar diffusion test and microplate laser nephelometry. Results: The bactericidal activity of chlorhexidine and octenidine was mainly $\mathrm{pH}$ independent in a pH range of 5.0-9.0. In contrast, polihexanide showed a significant efficacy increase at a higher $\mathrm{pH}$. It was also found that the influence of the $\mathrm{pH}$ on antiseptics differs among species of bacteria. For instance, S. aureus exhibited an increasing sensitivity against silver nitrate with rising $\mathrm{pH}$ whereas the effect on $P$. aeruginosa was found to be distinctly decreased. The antimicrobial effect of PVP-iodine was strongly diminished with rising $\mathrm{pH}$. Conclusions: The shift towards higher $\mathrm{pH}$ values in chronic wounds com-
\end{abstract}

pared to acute wounds makes it imperative to know whether the antimicrobial efficacy of applied antimicrobial substances is altered by different $\mathrm{pH}$ levels. The results suggest that application of polihexanide might be advantageous for the management of wound infections, as both $S$. aureus and $P$. aeruginosa exhibited an increased susceptibility with rising $\mathrm{pH}$.

(c) 2015 S. Karger AG, Basel

\section{Introduction}

An increasing number of patients suffer from wounds that fail to heal. This impaired wound healing derives from an imbalance between degradation and remodeling $[1,2]$. Several studies have shown that exudates from nonhealing wounds contain elevated levels of proteases, like matrix metalloproteinases and polymorphonuclear elastase [3-5]. In addition, infection plays a crucial role in compromised wound healing $[6,7]$. Contamination and infection of wounds can disrupt the regular healing sequence and result in a chronic inflammation, which hinders reepithelization [8-10]. Most chronic wounds are polymicrobial, and infections generally involve mixed populations of aerobic and anaerobic bacteria [11, 12]. Staphylococcus aureus is considered to be the most problematic germ in traumatic, surgical and burn wound infections $[12,13]$, but other microorganisms such as Pseu-

\begin{tabular}{|c|c|}
\hline KARGER 125: & $\begin{array}{l}\text { (c) } 2015 \text { S. Karger AG, Basel } \\
1660-5527 / 15 / 0283-0147 \$ 39.50 / 0\end{array}$ \\
\hline $\begin{array}{l}\text { E-Mail karger@karger.com } \\
\text { www.karger.com/spp }\end{array}$ & $\begin{array}{l}\text { This is an Open Access article licensed under the terms of the } \\
\text { Creative Commons Attribution-NonCommercial 3.0 Un- } \\
\text { ported license (CC BY-NC) (www.karger.com/OA-license), } \\
\text { applicable to the online version of the article only. Distribu- } \\
\text { tion permitted for non-commercial purposes only. }\end{array}$ \\
\hline
\end{tabular}

Cornelia Wiegand

Department of Dermatology, University Hospital Center Jena Erfurter Strasse 35

DE-07740 Jena (Germany)

E-Mail C.Wiegand@med.uni-jena.de 
domonas aeruginosa, Escherichia coli and Klebsiella pneumoniae may also play a role in chronic wound infection [13]. Hence, an antimicrobial treatment, based on systemic and topical antibiotics or using antiseptic substances, is often necessary to avoid or to eliminate wound infection. As the widespread use of antibiotics was associated with the emergence of resistant bacterial strains such as MRSA, antiseptics have become an important alternative in antimicrobial applications. The most commonly used substances in clinical settings are povidone (PVP)iodine, silver nitrate, chlorhexidine, octenidine and polihexanide $[14,15]$. However, only limited knowledge exists on the $\mathrm{pH}$ dependency of the antibacterial efficacy of these substances. It is of interest to investigate the influence of the $\mathrm{pH}$ on the performance of antiseptics or antimicrobial wound dressings as it has been shown that the $\mathrm{pH}$ in chronic wounds most commonly has a range of $6.5-8.5[16,17]$. This shift towards higher $\mathrm{pH}$ values in chronic wounds compared to acute wounds is called 'alkaline shift'. The alkalization is thought to be due to both tissue necrosis and the presence of microorganisms. Therefore, establishing a low physiological $\mathrm{pH}$ might be a key factor to aid wound healing. In vitro studies have shown that wound dressings can have significant effects on the $\mathrm{pH}$. Researchers found that shifts of up to $3 \mathrm{log}$ values towards both the alkaline and acidic milieu are possible [18]. Conversely, a recent study by Braunwarth et al. [19] demonstrated that the antimicrobial effect of polihexanide-containing biocellulose wound dressings is $\mathrm{pH}$-dependent, while silver-containing dressings possess similar bacteriostatic effects within a $\mathrm{pH}$ range of 5.5-9.0. These experiments were carried out using the agar diffusion test (ADT). Thus, the results do not only depend on the influence of the $\mathrm{pH}$ on the antibacterial activity but also on the diffusion capacity of the agent tested under different $\mathrm{pH}$. To further investigate the influence of the $\mathrm{pH}$ on the activity of antimicrobial substances and wound dressings, it would be advantageous to determine microbial growth using microplate laser nephelometry (MLN). MLN presents a valuable tool to investigate $\mathrm{pH}$ influence on antimicrobial activity, as it allows high-throughput screening, incubation over a prolonged time period, and in situ monitoring of changes in the dose-response curves as well as the half maximal inhibitory concentration $\left(\mathrm{IC}_{50}\right)$ [20-23]. This study uses both ADT and MLN to investigate the influence of the $\mathrm{pH}$ on the activity and the efficacy of common antiseptic substances, such as silver nitrate, polihexanide, chlorhexidine, octenidine and PVP-iodine. S. aureus and P. aeruginosa, the most prominent bacteria in wound infection $[12,24]$, have been used as model organisms. Moreover, the antibiotics vancomycin and gentamycin were included in the study for comparison.

\section{Materials and Methods}

\section{Materials}

The following antiseptic substances were selected for this study: silver nitrate (ACS reagent $\geq 99 \%$, Sigma, St. Louis, Mo., USA), polihexanide (Cosmocil ${ }^{\circledR}$ CQ 20\% polyhexamethylene biguanide, ARCH Chemicals, Rochester, N.Y., USA), chlorhexidine (chlorhexidine digluconate solution, $20 \%$ in $\mathrm{H}_{2} \mathrm{O}$, Sigma), octenidine $(0.5 \%$ octenidine dihydrochloride concentrate, Schülke \& Mayr GmbH, Norderstedt, Germany) and PVP-iodine (Sigma). The antibiotics vancomycin (hydrochloride, $\geq 900 \mathrm{IU} / \mathrm{mg}$, Carl Roth $\mathrm{GmbH}$, Karlsruhe, Germany) and gentamycin (sulphate, $\geq 590 \mathrm{IU} / \mathrm{mg}$, Carl Roth $\mathrm{GmbH}$ ) were used for comparison.

S. aureus ATCC 6538 and P. aeruginosa ATCC 27853 were purchased from the Deutsche Sammlung von Mikroorganismen und Zellkulturen, Germany. For cultivation of bacteria, special peptone and 'lab-lemco' powder for preparation of caso-bouillon and bacteriological agar were obtained from Oxoid (Basingstoke, UK). Columbia agar plates with $5 \%$ sheep blood were purchased from Biomeriéux (Marcy l'Etoile, France), $0.9 \% \mathrm{NaCl}$ solution was obtained from Fresenius Kabi Deutschland $\mathrm{GmbH}$ (Bad Homburg, Germany). Biodisks with gentamycin $(10 \mu \mathrm{g})$ and vancomycin $(30 \mu \mathrm{g})$ as well as additive-free disks were obtained from Biomeriéux, and $1 \mathrm{M} \mathrm{HCl}$ and $1 \mathrm{M} \mathrm{NaOH}$ were purchased from Carl Roth GmbH.

Evaluation of Antibacterial Activity at Different $p H$ by ADT

The ADT was performed in accordance with the DIN 58940-3. Caso-bouillon ( $\mathrm{pH} 7.0$ ) with different $\mathrm{pH}$ was prepared by addition of $\mathrm{HCl}$, yielding caso-bouillon with $\mathrm{pH} 6.0$ and 5.0, and by adding $\mathrm{NaOH}$, producing $\mathrm{pH} 8.0$ and 9.0, respectively. These media were supplemented with $1.5 \%$ agar, carefully heated until the agar was dissolved, and then cast into Petri dishes (Greiner BioOne, Essen, Germany; $10 \mathrm{ml}$ per dish) under sterile conditions. The prepared caso-agar plates were kept at $4^{\circ} \mathrm{C}$ until use. Twenty milliliters of caso-bouillon ( $\mathrm{pH}$ 7.0) were inoculated with 1-2 colonies of the test organisms grown on Columbia agar plates and incubated for $24 \mathrm{~h}$ at $37^{\circ} \mathrm{C}$ under shaking. These $S$. aureus and $P$. aeruginosa cell suspensions were diluted 1:100 using the casobouillon with adjusted $\mathrm{pH}$. These working suspensions had a microbial count of app. $1-5 \times 10^{6} \mathrm{CFU} / \mathrm{ml}$, and $100 \mu$ lof these suspensions were plated on the prepared caso-agar plates and left to dry for $10 \mathrm{~min}$. Afterwards, the disks were placed onto the inoculated agar plates and wetted with $20 \mu \mathrm{l}$ of each antiseptic. Negative controls (disks without additive) and positive controls (S. aureus: biodisks with $30 \mu \mathrm{g}$ vancomycin and $P$. aeruginosa: biodisks with $10 \mu \mathrm{g}$ gentamycin) were soaked with $20 \mu \mathrm{l} 0.9 \% \mathrm{NaCl}$. All plates were incubated for $24 \mathrm{~h}$ at $37^{\circ} \mathrm{C}$. The zone of inhibition (ZOI) was then measured in millimeters and all plates were photographed for documentation.

Determination of Efficacy of Antiseptics at Different $p H$ by $M L N$

MLN was performed in accordance with National Committee for Clinical Laboratory Standards documents M27-A2 and DIN 
EN 27027. Caso-bouillon ( $\mathrm{pH} 7.0$ ) with a different $\mathrm{pH}$ was prepared by adding $\mathrm{HCl}$, yielding caso-bouillon with $\mathrm{pH} 6.0$, and $\mathrm{NaOH}$, producing $\mathrm{pH} 8.0$ and 9.0, respectively. Twenty milliliters of caso-bouillon ( $\mathrm{pH} 7.0$ ) were inoculated with 1-2 colonies of the test organisms grown on Columbia agar plates and incubated for $24 \mathrm{~h}$ at $37^{\circ} \mathrm{C}$ under shaking. These $S$. aureus and $P$. aeruginosa cell suspensions were diluted $1: 10^{5}$ in serial steps using the caso-bouillon with adjusted $\mathrm{pH}$. These working suspensions had a microbial count of approx. $5 \times 10^{3} \mathrm{CFU} / \mathrm{ml}$, and $100 \mu \mathrm{l}$ of these suspensions were put in the respective wells of the 96-well microplate that contained the prepared dilutions of the antiseptics. Serial dilutions of the test substances were prepared in $0.9 \% \mathrm{NaCl} ; 100 \mu \mathrm{l}$ each were put in triplicate into the respective wells of a sterile, clear, 96-well microplate (Greiner Bio-One). Blanks for each substance concentration tested were run at every assay. The microplates were covered with a clear adhesive film (Greiner Bio-One). The adhesive film was punctured with a 25 -gauge needle at the right brim of the well to allow gas exchange. The microplates were then placed in the microplate laser nephelometer (NEPHELOstar Galaxy, BMG Labtech, Offenburg, Germany) and incubated for $24 \mathrm{~h}$ at $37^{\circ} \mathrm{C}$. During incubation, the microplates were shaken in the instrument except during the hourly measurement. To determine the growth of the microorganisms, the turbidity was plotted against the incubation time for each antiseptic concentration tested. Subsequently, the 'area under the curve' was determined from the results and calculated as a percentage of the untreated control [bacterial growth (\%)]. This was used to realize a dose-response curve for each antiseptic tested at the different $\mathrm{pH}$ from which the $\mathrm{IC}_{50}$ of the antiseptics (under the experimental conditions used) was calculated, using a logistic fit function $[\mathrm{y}=\mathrm{A} 2+(\mathrm{A} 1-\mathrm{A} 2) /(1+(\mathrm{x} /$ $\mathrm{x} 0)^{\wedge} \mathrm{p}$ ] where $\mathrm{A} 1$ is the upper limit, $\mathrm{A} 2$ is the lower limit, $\mathrm{x} 0$ is the $\mathrm{IC}_{50}$ and $\mathrm{p}$ is the slope of the curve (Origin 7.5, OriginLab, Northampton, Mass., USA).

\section{Statistical Analysis}

One-way analysis of variance was carried out to determine statistical significance (Microsoft ${ }^{\circledR}$ Excel 2000). Differences were considered statistically significant at a level of $p<0.05$. Asterisks indicate significant deviations from the control at the respective incubation time $\left({ }^{*} \mathrm{p}<0.05\right.$; $^{* *} \mathrm{p}<0.01$; $\left.^{* * *} \mathrm{p}<0.001\right)$.

\section{Results}

\section{The pH Affects Bacterial Growth in Solution}

MLN was used to monitor the growth of $S$. aureus and $P$. aeruginos $a$ at different $\mathrm{pH}$ by the turbidity of the respective solution (fig. 1a, b). While turbidity requires relatively high concentrations of particles and obeys Beer's law, MLN uses a laser beam and measures its scattering by particles in solution at a right or forward angle. Compared to other methods used $[25,26]$, it enables highthroughput screening of several antiseptics at different $\mathrm{pH}$ in a short time. Furthermore, it allows the in situ recording of dose-response curves and the simultaneous monitoring of the $\mathrm{IC}_{50}$ value $[20,21]$. It was found that a low $\mathrm{pH}$ (5.0) effectively inhibited microbial growth in solution. While no difference in the growth of $S$. aureus and $P$. aeruginosa was observed at $\mathrm{pH}$ 7.0-9.0, their progeny at $\mathrm{pH} 5.0$ was found to be reduced to $<10 \%$ of the control at $\mathrm{pH} 7.0$ (fig. 1c).

The ADT was performed in accordance with the DIN 58940-3. In contrast to the experiments using MLN, bacteria did still grow on caso-agar plates with a low $\mathrm{pH}$ of 5.0. After $24 \mathrm{~h}$, culture plates were completely covered with bacterial lawn at all $\mathrm{pH}$ values tested (fig. 2). As positive controls for ADT disks containing vancomycin (30 $\mu \mathrm{g}$, S. aureus) and gentamycin $(10 \mu \mathrm{g}$, P. aeruginosa $)$ were used. Positive controls were effective at each $\mathrm{pH}$ tested; however, a significant influence on ZOI formation could be observed.

\section{Determination of the Influence of the $\mathrm{pH}$ on}

Antibacterial Activity by ADT

Caso-agar plates with different $\mathrm{pH}$ values $(5.0,6.0,7.0$, 8.0 and 9.0) were inoculated with $S$. aureus (fig. 3a) or $P$. aeruginosa (fig. $3 \mathrm{~b}$ ). It could be noted that the antibiotics vancomycin and gentamycin used as positive controls also exhibited a pH-dependent activity. Here, bactericidal efficacy decreased with increasing $\mathrm{pH}$ for vancomycin (fig. 3a), while gentamycin (fig. 3b) showed enhanced effects at a higher $\mathrm{pH}$.

Further experiments evaluated the influence of the $\mathrm{pH}$ on the antibacterial activity of the antiseptic substances selected (fig. 3). All substances were tested in concentrations that would be applied in clinical settings. The silver nitrate solution $(0.1 \%)$ caused an average ZOI of $10 \mathrm{~mm}$ and was equally effective against $S$. aureus and $P$. aeruginosa. No changes in ZOIs were observed with different $\mathrm{pH}$ values. Chlorhexidine $(0.2 \%)$ was able to inhibit the growth of $S$. aureus and $P$. aeruginosa in a similar fashion. No significant difference in the antibacterial efficacy was found between $\mathrm{pH} 6$ and $\mathrm{pH}$ 9. Yet, at $\mathrm{pH}$ 5, a slightly higher activity was observed; however, a significant difference in the size of the $\mathrm{ZOI}$ at $\mathrm{pH} 5$ compared to $\mathrm{pH} 7$ was only observed for $S$. aureus $(\mathrm{p}<0.001, P$. aeruginosa: n.s.). Moreover, octenidine (0.1\%) exhibited a $\mathrm{pH}$-independent antibacterial activity against $S$. aureus and $P$. aeruginosa in vitro. In contrast, polihexanide $(0.04 \%)$ exhibited increased efficacy against $S$. aureus with a rising $\mathrm{pH}$. It was also found that the antibacterial activity of polihexanide against $P$. aeruginosa increased from $\mathrm{pH} 7$ to $\mathrm{pH}$ 9. However, larger ZOIs were found at $\mathrm{pH} 5$ and 6 compared to at $\mathrm{pH}$ 7. PVP-iodine (10\%) showed a significant loss of antibacterial efficacy against both $S$. aureus and $P$. aeruginosa with a rising $\mathrm{pH}$. 


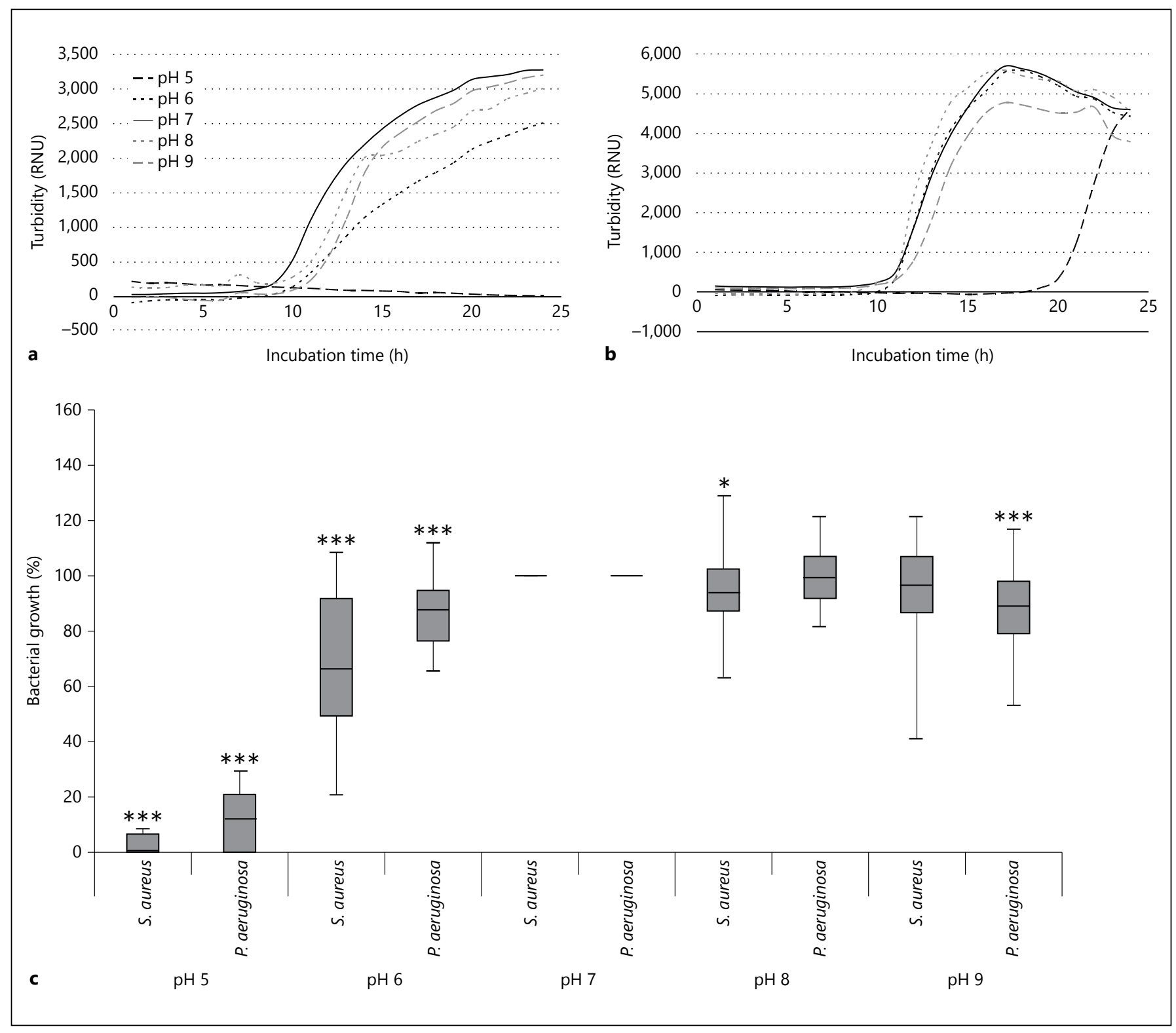

Fig. 1. Growth curves of $S$. aureus (a) and P. aeruginosa $(\mathbf{b})$ at $\mathrm{pH}$ 5.0, 6.0, 7.0, 8.0 and 9.0 determined by MLN. c Bacterial growth at $37^{\circ} \mathrm{C}$ after $24 \mathrm{~h}$ at the respective $\mathrm{pH}$ values was compared to the medium control at $\mathrm{pH}$ 7.0. It was found that a low $\mathrm{pH}$ of 5.0 effectively inhibits the growth of $S$. aureus and diminishes $P$. aeruginosa progeny in solution. Asterisks indicate significant deviations from the control at $\mathrm{pH} 7.0\left(^{*} \mathrm{p}<0.05\right.$; ${ }^{* *} \mathrm{p}<0.01$; *** $\mathrm{p}<0.001)$.

\section{Employing MLN to Evaluate the pH Effect on}

Antibacterial Activity

Although the ADT offers the possibility to observe changes in situ, it depends on the diffusion capacity of the active agent tested. Large molecules may have a reduced ability to disperse through the agar compared to smaller molecules, or their charge might impede diffusion. In both cases, the test outcome is influenced. As MLN inves- tigations are performed in solution, they do not depend on the diffusion capacity of the substances and enable the direct measurement of interactions between substance and germs.

Results are summarized in figures 4 and 5 . Because low $\mathrm{pH}$ (5.0) inhibited microbial growth in solution, MLN tests were only performed at a $\mathrm{pH}$ range of 6.0-9.0. At these $\mathrm{pH}$ values, no significant differences in the bacteri- 


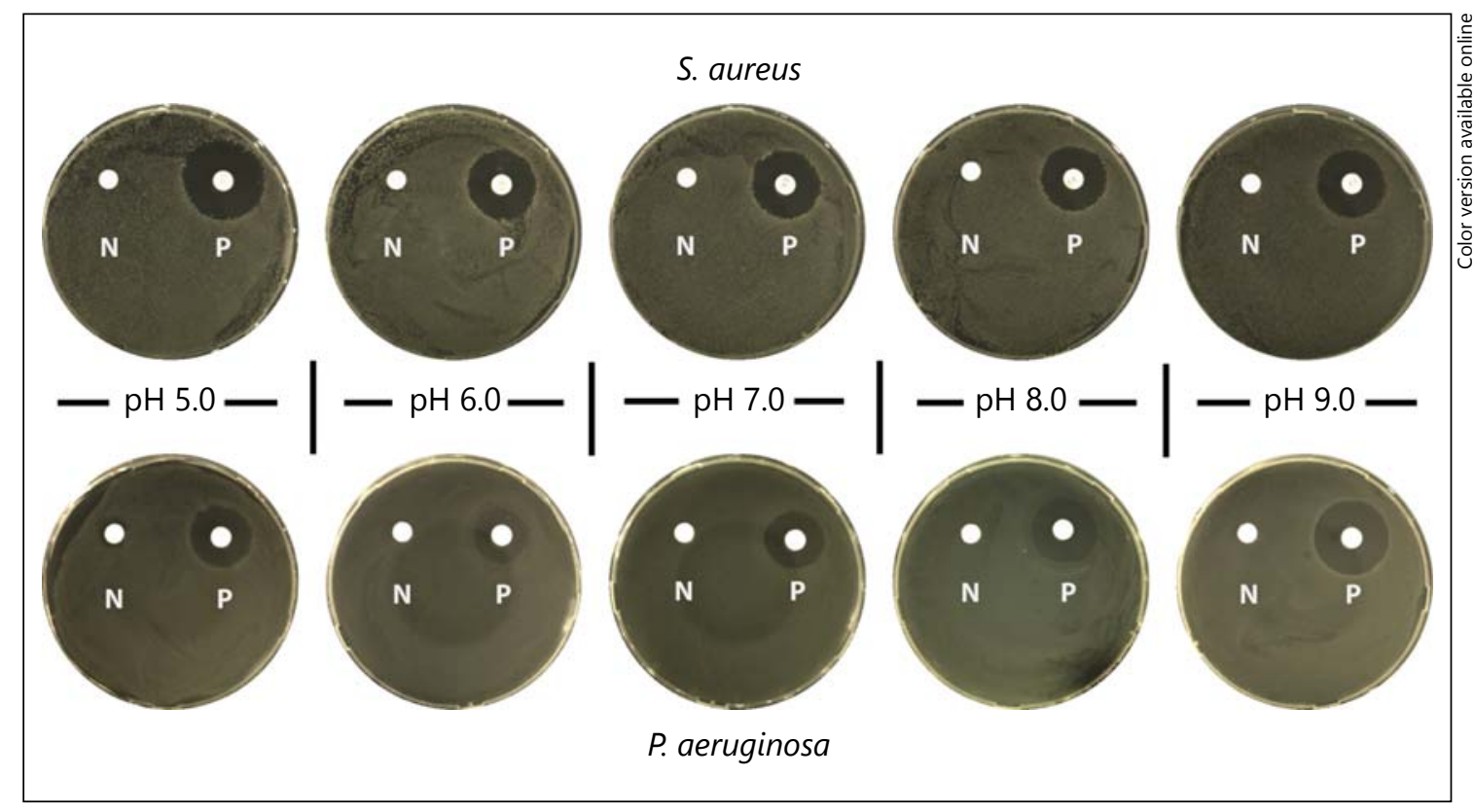

Fig. 2. Caso-agar plates with different $\mathrm{pH}$ were inoculated with $S$. aureus and $P$. aeruginosa and incubated at $37^{\circ} \mathrm{C}$ for $24 \mathrm{~h}$. Plates were completely covered with a bacterial lawn at all $\mathrm{pH}$ values test-

cidal activity of vancomycin against $S$. aureus were observed. In contrast, the efficacy of gentamycin against $P$. aeruginosa increased significantly from $\mathrm{pH} 6.0$ to $\mathrm{pH} 9.0$. Moreover, it could be shown that most antiseptics possess a $\mathrm{pH}$-dependent antimicrobial activity. For instance, a significant influence of the $\mathrm{pH}$ on the efficacy of silver nitrate, polihexanide and PVP-iodine was found in vitro. In addition, it was observed that the influence of the $\mathrm{pH}$ on the efficacy of the antiseptics differed among the bacteria strains tested. S. aureus exhibited an increasing sensitivity against both silver nitrate and polihexanide with a rising $\mathrm{pH}$. It could be shown that the $\mathrm{IC}_{50}$ values of polihexanide significantly decreased from 0.5 (at pH 6.0) to $0.05 \mu \mathrm{g} / \mathrm{ml}$ (at pH 9.0) and for silver nitrate from 2.1 (at $\mathrm{pH} 6.0$ ) to $0.5 \mu \mathrm{g} / \mathrm{ml}$ (at $\mathrm{pH} 9.0$ ). P. aeruginosa displayed an enhanced sensitivity only for polihexanide. Here, $\mathrm{IC}_{50}$ values decreased from 0.6 (at $\mathrm{pH} 6.0$ ) to $0.2 \mu \mathrm{g} / \mathrm{ml}$ (at $\mathrm{pH}$ 9.0). In contrast, 2.3-times more silver nitrate was necessary at a higher $\mathrm{pH}$ to achieve a similar growth reduction of $P$. aeruginosa in vitro. While both $S$. aureus and $P$. aeruginosa exhibited an increased sensitivity against polihexanide with a rising $\mathrm{pH}$, the efficacy of $\mathrm{PVP}$-iodine was significantly reduced. In particular, the ability of PVPiodine to reduce the growth of $S$. aureus was markedly affected. This is in accordance with the ADT results. The antibacterial activity of the antiseptics chlorhexidine and ed. Positive $(\mathrm{P})$ controls (S. aureus: vancomycin and P. aeruginosa: gentamycin) exhibited different effects depending on the $\mathrm{pH}$. Negative $(\mathrm{N})$ controls did not induce a $\mathrm{ZOI}$. octenidine was only marginally affected by the $\mathrm{pH}$ in vitro. No significant changes were observed for chlorhexidine, while comparison of the $\mathrm{IC}_{50}$ values for octenidine at different $\mathrm{pH}$ values revealed a slight but statistically significant decrease against $S$. aureus at pH 9.0.

\section{Discussion}

$\mathrm{pH}$ is defined as the negative logarithm of the activity of hydrogen ions in aqueous solution and is used to express acidity and alkalinity on a scale of $0-14$. The $\mathrm{pH}$ of normal skin ranges from about 4.0 to 6.0 and has been recognized as the 'acid mantle' of the skin. It is of vital importance for the skin function and its resistance to external noxa [27]. The $\mathrm{pH}$ milieu in wounds has a direct as well as an indirect influence on many factors during wound healing. Studies have shown that the $\mathrm{pH}$ of chronic wounds most commonly has a range of 6.5-8.5 while the $\mathrm{pH}$ of acute, healing wounds is significantly lower $[16,17]$. This alkalization or 'alkaline shift' is thought to be due to tissue necrosis and the presence of microorganisms. Hence, establishing a low physiological $\mathrm{pH}$ might aid wound healing [27]. Chemical acidification of the wound bed is thought to reduce bioburden as the growth of most human pathogens is inhibited at $\mathrm{pH}$ levels $<6.0$ 
Fig. 3. For the ADT, caso-agar plates with different $\mathrm{pH}$ were inoculated with $S$. aureus (a) or $P$. aeruginosa (b) and incubated with the antimicrobial substances at $37^{\circ} \mathrm{C}$ for 24 h. Afterwards, the ZOI was measured. Vancomycin and gentamycin were used as positive controls. The negative controls did not induce a ZOI. Asterisks indicate significant deviations from results at $\mathrm{pH} 7.0$ (* $\left.\mathrm{p}<0.05 ;{ }^{* *} \mathrm{p}<0.01 ;{ }^{* * *} \mathrm{p}<0.001\right)$.

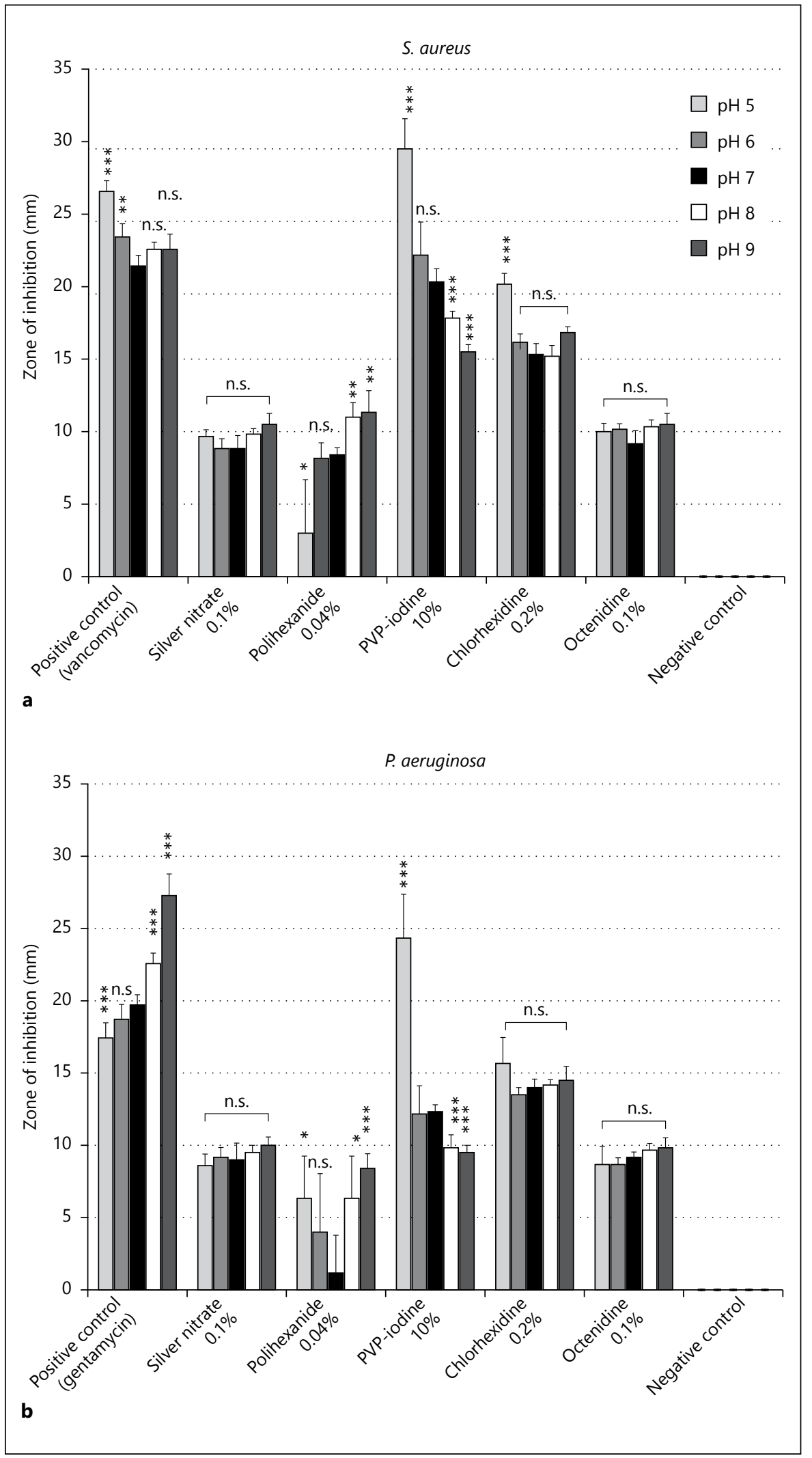




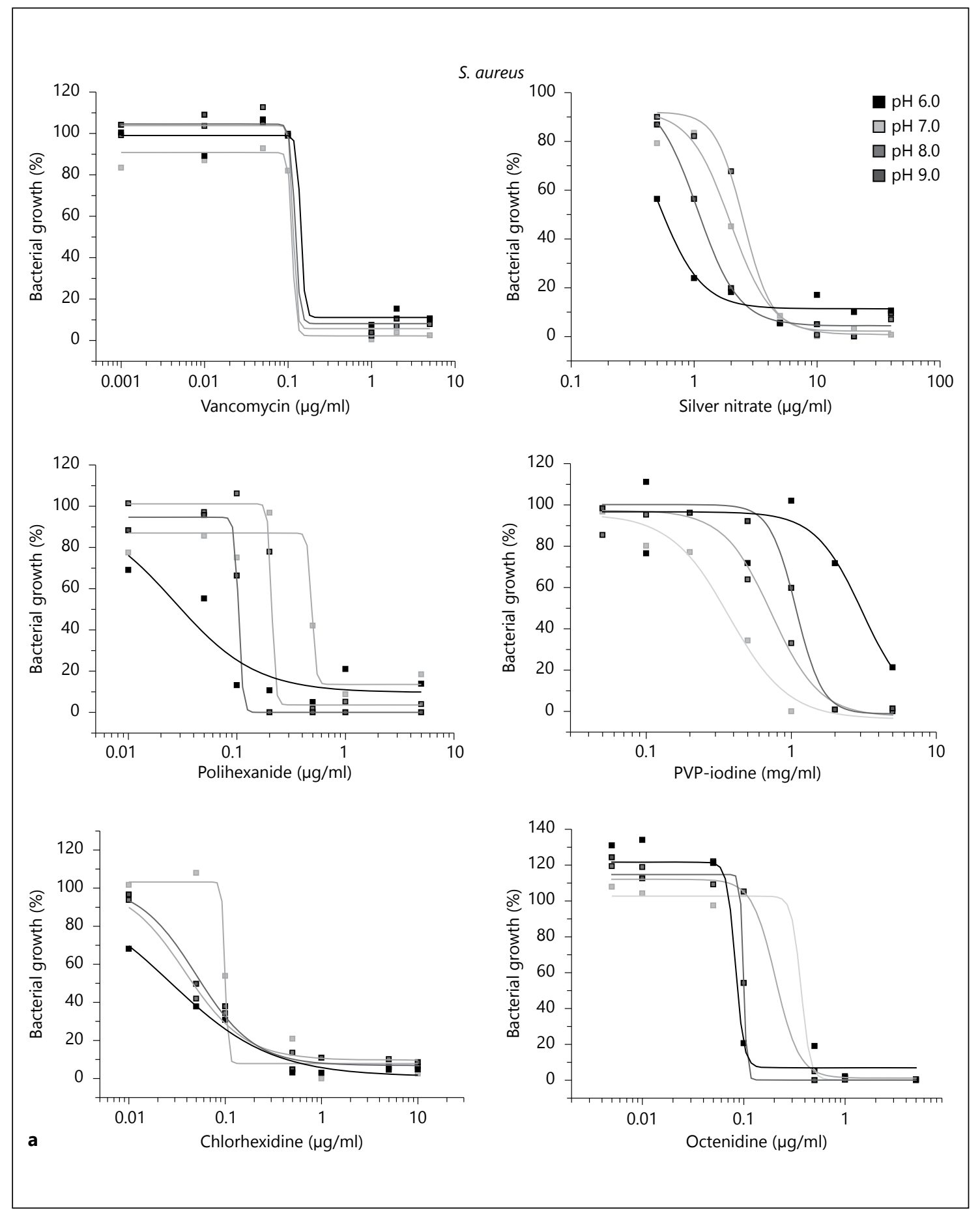

Fig. 4. Dose-response curves at different $\mathrm{pH}$ for the antibiotics vancomycin and gentamycin as well as for the antiseptic substances silver nitrate, polihexanide, PVP-iodine, chlorhexidine and octenidine against S. aureus (a) and $P$. aeruginosa $(\mathbf{b})$ were recorded using MLN.

(For figure $4 b$ see next page.) 


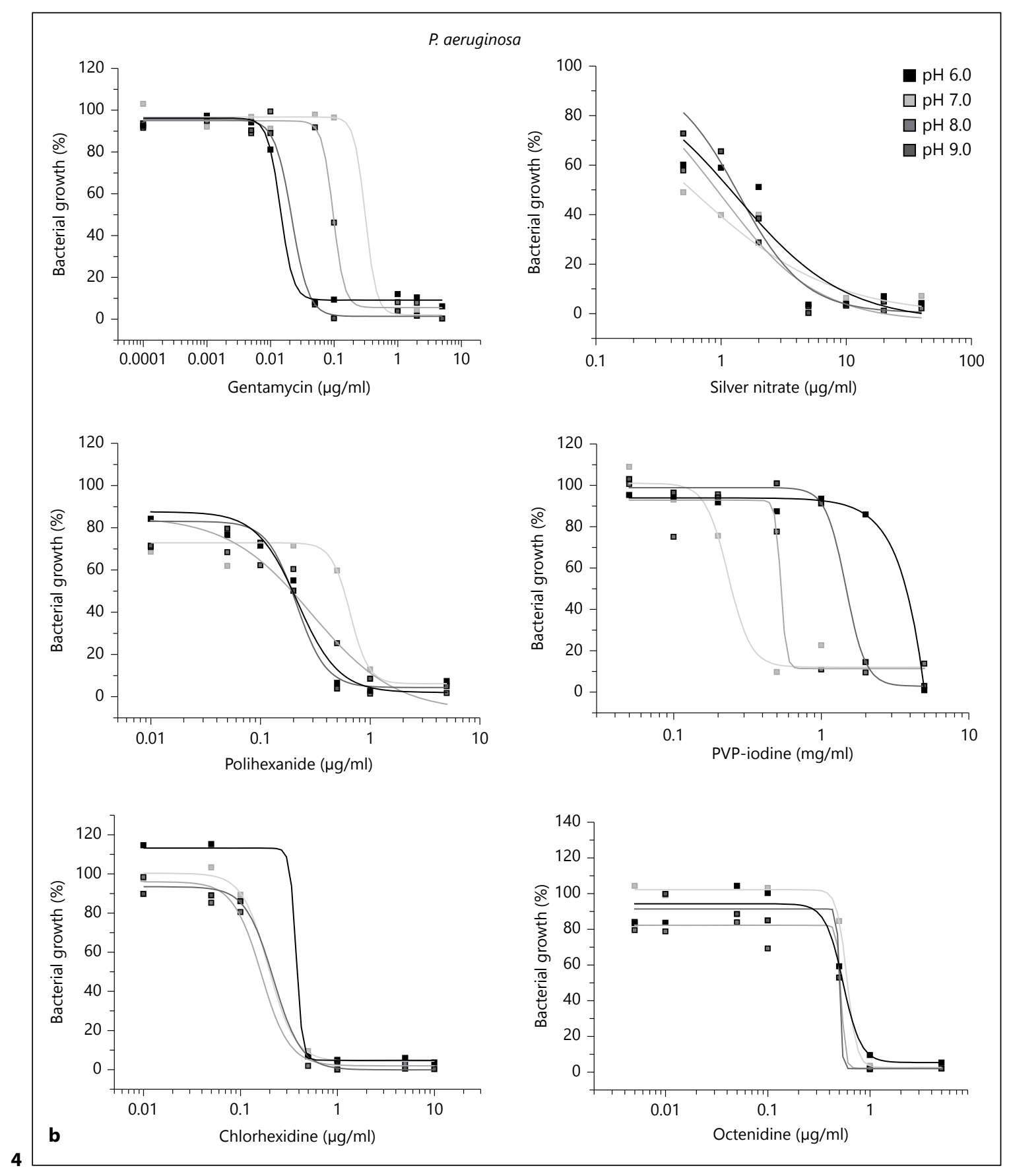

[17]. This could be confirmed by tests using MLN where acidic $\mathrm{pH}$ led to a significant decrease of bacterial growth. However, no significant effect on the growth of $S$. aureus and $P$. aeruginosa was observed on the agar plates at $\mathrm{pH}$ 5.0. This could indicate that the colonization of a surface enables bacteria to change the $\mathrm{pH}$ of their environment, e.g. the bacterial colonization of intact skin is accompanied by an increase of the local $\mathrm{pH}$ [17]. Therapeutic prospects are clearly conceivable from these results. In vitro studies show that wound dressings can have significant effects on the $\mathrm{pH}$ [18]. However, the inverse question has to be raised, i.e. whether wound $\mathrm{pH}$ affects the activity and efficacy of antimicrobial agents. As chronic wounds are frequently colonized by different kinds of microorganisms, the most prominent being $S$. aureus and $P$. aeruginosa $[12,24]$, an antimicrobial 


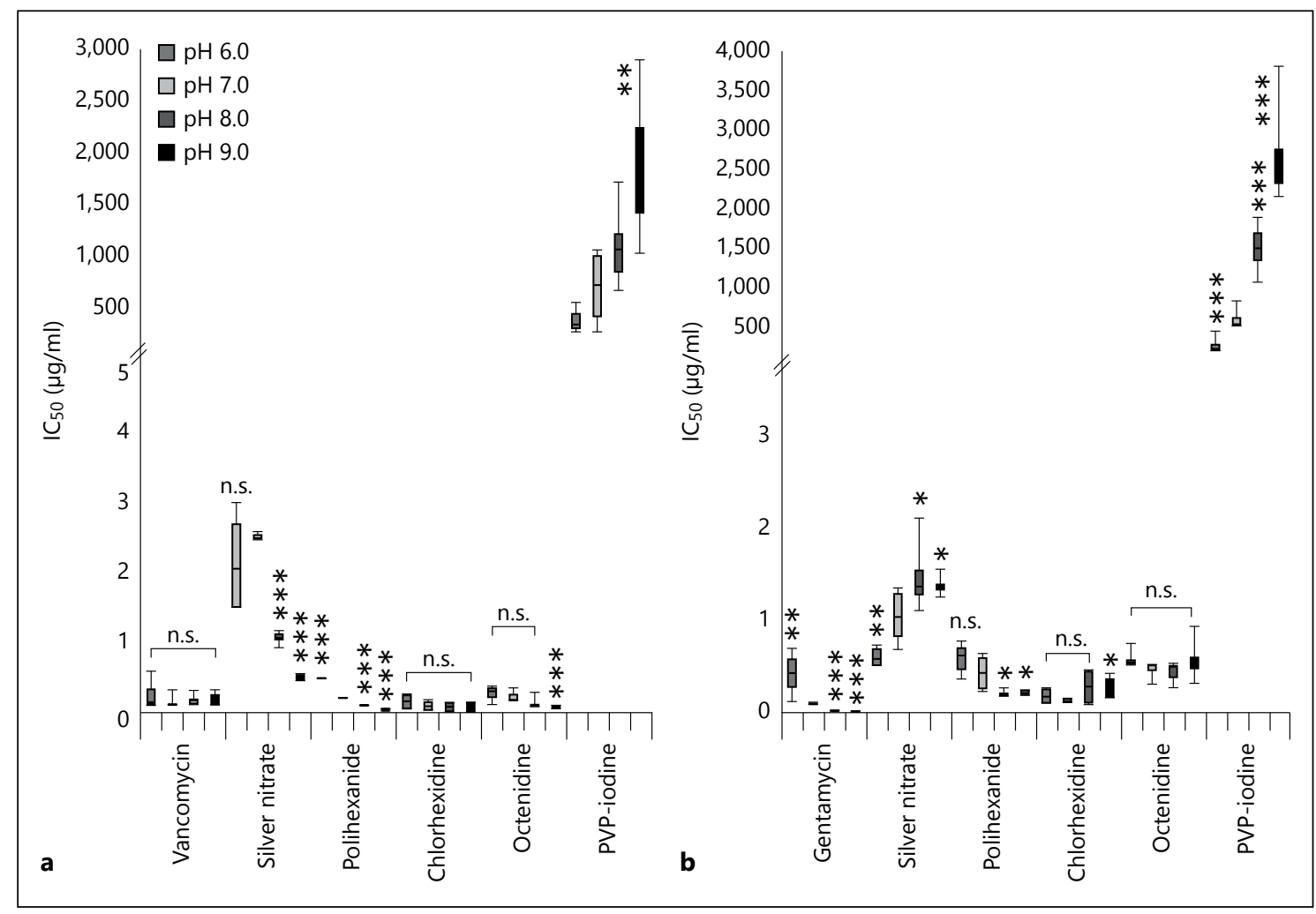

Fig. 5. The specific $\mathrm{IC}_{50}$ were calculated from the dose-response curves recorded at different $\mathrm{pH}$ for the antimicrobial substances tested against $S$. aureus (a) and $P$. aeruginosa (b) using MLN. Asterisks indicate significant deviations from results obtained at $\mathrm{pH} 7.0\left(^{*} \mathrm{p}<0.05\right.$; $^{* *} \mathrm{p}<0.01$; $\left.^{* *} \mathrm{p}<0.001\right)$.

treatment is often necessary to avoid or eliminate wound infection. Hence, it is of interest to investigate the influence of the $\mathrm{pH}$ on the performance of antimicrobial substances. The results presented here show that most antiseptics as well as antibiotics possess a $\mathrm{pH}$-dependent antimicrobial activity. The most pronounced influence on antibacterial efficacy was observed for polihexanide, PVP-iodine and gentamycin in vitro. However, while polihexanide and gentamycin displayed an increasing activity with rising $\mathrm{pH}$, the antimicrobial effect of $\mathrm{PVP}$-iodine was significantly reduced.

Polihexanide (fig. 6) exhibited an enhanced bactericidal efficacy against $S$. aureus and $P$. aeruginosa in the MLN measurements with increasing $\mathrm{pH}$. As expected, the polycation was found to be more effective against the Gram-positive bacteria S. aureus compared to the Gramnegative bacteria $P$. aeruginosa. These differences in the bactericidal capacity can be explained by the differences in the cell wall properties of Gram-positive and Gramnegative bacteria [15]. In the ADT, polihexanide showed an increase of antibacterial activity against $S$. aureus in the
$\mathrm{pH}$ range of 5.0-9.0; for $P$. aeruginosa, a higher efficacy was also observed from $\mathrm{pH} 7$ to $\mathrm{pH}$ 9. However, larger ZOIs were found at $\mathrm{pH} 5.0$ and $\mathrm{pH} 6.0$ compared to at $\mathrm{pH}$ 7.0. This could be due to differences in the diffusion capacity of polihexanide at the respective $\mathrm{pH}$ values and/or might be caused by the particular features of $P$. aeruginos $a$ at low $\mathrm{pH}$ values. The overall increase of the efficacy of polihexanide against both species with rising $\mathrm{pH}$ can be explained by its polycationic nature. At physiological $\mathrm{pH}$, the positively charged groups of polihexanide can bind rapidly to the negatively charged surface of the bacteria. This causes membrane damage and the death of the bacteria [28]. In an alkaline solution, the biguanid groups present can still become protonated due to their pKa value of 10.96, which leads to a higher charge density intensifying the binding to the bacterial surface [29] and maybe the higher antimicrobial activity observed.

Gentamycin (fig. 6) is an aminoglycoside antibiotic used to treat severe infections by Gram-negative bacteria. Its mechanism of action is to inhibit bacterial protein synthesis by binding to the 70S-ribosomal subunit and hin- 


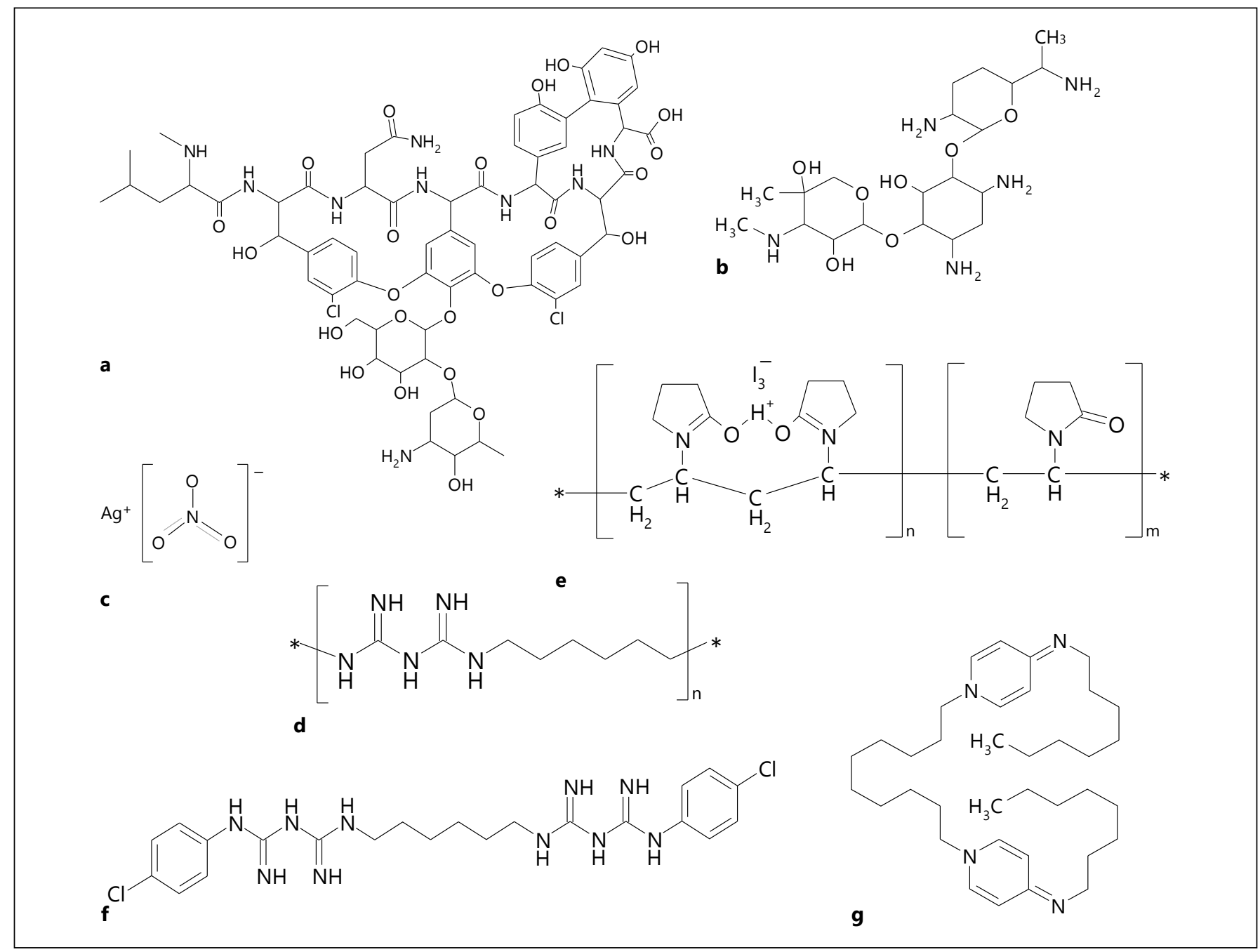

Fig. 6. Comparison of the chemical structures of vancomycin (a), gentamycin (b), silver nitrate (c), polihexanide (d), PVP-iodine (e), chlorhexidine (f) and octenidine ( $\mathbf{g})$. Asterisks indicate chain elongations by subunits depicted.

dering aminoacyl-tRNA transfer. At a higher $\mathrm{pH}$, the uptake of gentamycin might be increased, as the alkalization of the environment also changes the bacterial membrane, leading to either more or less susceptibility to antimicrobial substances [15]. Moreover, it is known that the trisaccharide structure of gentamycin can be damaged by acidic treatment, causing inactivation of the aminoglycoside antibiotic at a lower $\mathrm{pH}[30]$.

In contrast, PVP-iodine, the complex of polyvinyl pyrrolidone and triiodine ions (fig. 6) with a broad microbicidal spectrum, is not active beyond $\mathrm{pH} 7$ [31]. Hence, although iodine acts very quickly [32], a significant loss of its antibacterial efficacy can be observed, increasing the $\mathrm{pH}$ from 5.0 to 9.0. Here, similar results were obtained in both test systems for $S$. aureus and $P$. aeruginosa.
Results for vancomycin and silver nitrate differed between ADT and MLN. While vancomycin (fig. 6) displayed a significantly higher bactericidal effect at a lower $\mathrm{pH}$ in the ADT, no significant difference in the antibacterial activity was observed with MLN. Vancomycin is a large glycopeptide antibiotic used in the treatment of infections caused by Gram-positive bacteria. It acts by inhibiting their cell wall synthesis by forming bonds with the terminal D-alanyl-D-alanine moieties of the NAM/ NAG-peptides, which prevents their elongation and cross-linking to fashion a solid cell wall. As MLN did not show significant differences in the bactericidal effect at the $\mathrm{pH}$ range tested, the increase of the antibacterial activity observed by $\mathrm{ADT}$ was most likely due to a different charge distribution and resulting differences in the diffu- 
sion capacities of the antibiotic. In contrast, silver nitrate did not show a pH-dependent effect in the ADT but exhibited $\mathrm{pH}$ sensitivity during MLN. Unlike the antibiotic, the silver ion $\left(\mathrm{Ag}^{+}\right)$works on multiple components of bacterial cell metabolism. Silver ions react with inorganic compounds, organic acids, proteins, DNA and RNA, killing the microorganisms through inhibition of cellular respiration, interference with DNA replication and alteration of cellular membrane permeability [8]. Besides, the diffusion capacity of the small silver ion is unlikely to be altered by $\mathrm{pH}$ in the ADT. Interestingly, it was observed that the influence of the $\mathrm{pH}$ on silver nitrate efficacy in MLN differs among bacteria. While $S$. aureus exhibited an increasing sensitivity against silver nitrate with a rising $\mathrm{pH}$, about 2 times more silver nitrate was necessary at $\mathrm{pH}$ 9.0 compared to at $\mathrm{pH} 6.0$ to achieve a similar growth reduction of $P$. aeruginosa. This might indicate that an alkaline environment has different effects on bacteria species [15]; it increases the susceptibility of $S$. aureus but it might strengthen the defiance of $P$. aeruginosa.

Like polihexanide, chlorhexidine and octenidine are positively charged (fig. 6) and exhibit their effect by interacting with negatively charged molecules in the bacterial cell membranes, resulting in their disruption. It could be shown that these positively charged antiseptics can induce the aggregation of acidic lipids in the vicinity of the adsorption site, which changes membrane permeability and may alter the function of membrane-associated enzymes, causing a leakage of cytoplasmatic compounds such as $\mathrm{K}^{+}[15]$. Moreover, the increased permeability of the cell wall allows small molecules like chlorhexidine and octenidine to penetrate into the bacteria cell and act on targets within the bacteria [33]. Here, chlorhexidine and octenidine precipitated, for the most part, only slight changes in the antibacterial activity at different $\mathrm{pH}$ values in MLN as well as in ADT. It is most likely that the $\mathrm{pH}$ effect on these substances is less notable due to their lower molecular weight compared to the polycation polihexanide [29]. Hence, it is improbable that their charge density is altered with rising $\mathrm{pH}$ in the same way as polihexanide is affected.

In conclusion, the treatment of wound infections has an important role in wound management. A high bioburden will disrupt the normal healing process and lead to development of persistent, nonhealing wounds [8-10]. The presence of bacteria further leads to the alkalization of the wound environment. It has been shown that the $\mathrm{pH}$ in chronic wounds most commonly has a range of 6.5-8.5 $[16,17]$. This shift towards higher $\mathrm{pH}$ values in chronic wounds compared to acute wounds makes it imperative to know whether the antimicrobial efficacy of applied antimicrobial substances is altered by different $\mathrm{pH}$ levels. Our results suggest that the application of polihexanide might be advantageous for the management of wound infections, as both S. aureus and P. aeruginosa displayed an increased susceptibility with raised $\mathrm{pH}$.

\section{Acknowledgements}

This work was partially supported by Lohmann \& Rauscher $\mathrm{GmbH} \& \mathrm{Co}$. KG (Germany). The authors would like to thank Denise Reichmann for excellent technical assistance.

\section{References}

1 Nwomeh BC, Yager DR, Cohen IK: Physiology of the chronic wound. Clin Plast Surg 1998;25:341-356.

$\checkmark 2$ Mast BA, Schultz GS: Interactions of cytokines, growth factors, and proteases in acute and chronic wounds. Wound Rep Reg 1996;4: 411-420.

3 Barrick B, Campbell EJ, Owen CA: Leukocyte proteinases in wound healing: roles in physiologic and pathologic processes. Wound Rep Reg 1999;7:410-422.

-4 Trengove NJ, Stacey MC, MacAuley S, Bennett N, Gibson J, Burslem F, Murphy G, Schultz G: Analysis of the acute and chronic wound environments: the role of proteases and their inhibitors. Wound Rep Reg 1999;7:442-452.

5 Yager DR, Nwomeh BC: The proteolytic environment of chronic wounds. Wound Rep Reg 1999;7:433-441.
6 Sibbald RG, Orsted H, Schultz GS, Coutts P, Keast D: Preparing the wound bed 2003: focus on infection and inflammation. Ostomy Wound Manage 2003;49:23-51.

7 Falanga V: Classifications for wound bed preparation and stimulation of chronic wounds. Wound Rep Reg 2000;8:347-352.

$\checkmark 8$ Warriner R, Burrell R: Infection and the chronic wound: a focus on silver. Adv Skin Wound Care 2005;18:2-12.

-9 Kingsley A: The wound infection continuum and its application to clinical practice. Ostomy Wound Manage 2003;49:1-7.

-10 Wright JB, Lam K, Buret AG, Olson ME, Burrell RE: Early healing events in a porcine model of contaminated wounds: effects of nanocrystalline silver on matrix metalloproteinases, cell apoptosis, and healing. Wound Rep Reg 2002;10:141-151.
1 Gjødsbøl K, Christensen JJ, Karlsmark T, Jørgensen B, Klein BM, Krogfelt KA: Multiple bacterial species reside in chronic wounds: a longitudinal study. Int Wound J 2006;3:225231.

12 Dissemond J, Schmid EN, Esser S, Witthoff M, Goos M: Bakterielle Kolonisation chronischer Wunden. Hautarzt 2004;55:280-288.

13 Bowler PG, Duerden BI, Armstrong DG: Wound microbiology and associated approaches to wound management. Clin Microbiol Rev 2001;14:244-269.

14 White RJ, Cutting K, Kingsley A: Topical antimicrobials in the control of wound bioburden. Ostomy Wound Manage 2006;52:2658.

15 McDonnell G, Russell AD: Antiseptics and disinfectants: activity, action and resistance. Clin Microbiol Rev 1999;12:147-179. 
16 Eberlein T: Experience in Europe. 12th Congress of the German Society of Woundhealing, Freiburg, 2010.

17 Dissemond J, Witthoff M, Brauns TC, Haberer D, Goos M: pH-Wert des Milieus chronischer Wunden. Hautarzt 2003;54:959-965.

18 Weindorf M: pH-Werte moderner Wundauflagen und deren Einfluss auf das umgebende Milieu: Resultate einer in vitro Untersuchung. ZfW 2007;12:92-97.

19 Braunwarth H, Brill FHH, Brill H: Results of in vitro testing of wound dressings with sustained release of polihexanide (PHMB) and silver-ions at different $\mathrm{pH}$-values. Wound Manage 2011;3:119-125.

20 Finger S, Wiegand C, Buschmann H-J, Hipler U-C: Antimicrobial properties of cyclodextrin-antiseptics-complexes determined by microplate laser nephelometry and ATP bioluminescence assay. Int J Pharm 2012;436: 851-856.

21 Wiegand C, Abel M, Ruth P, Hipler U-C Analysis of the adaptation capacity of Staphylococcus aureus to commonly used antiseptics by microplate laser nephelometry. Skin Pharmacol Physiol 2012;25:288-297.
22 Seyfarth F, Schliemann S, Elsner P, Hipler U-C: Antifungal effect of high- and low-molecular-weight chitosan hydrochloride, carboxymethyl chitosan, chitosan oligosaccharide and $\mathrm{N}$-acetyl-D-glucosamine against Candida albicans, Candida krusei and Candida glabrata. Int J Pharm 2008;353:139-148.

23 Fouda MMG, Knittel D, Hipler U-C, Elsner P. Schollmeyer E: Antimycotic influence of $\beta$-cyclodextrin complexes - in vitro measurements using laser nephelometry in microtiter plates. Int J Pharm 2006;311:113-121.

24 Kirketerp-Moller K, Jensen PO, Fazli M, Madsen KG, Pedersen J, Moser C, TolkerNielsen T, Hoiby N, Giuskov M, Bjarnsholt T: Distribution, organization, and ecology of bacteria in chronic wounds. J Clin Microbiol 2008;46:2717-2722.

25 Walsh SE, Maillard J-Y, Russell AD, Catrenich CE, Charbonneau DL, Bartolo RG: Development of bacterial resistance to several biocides and effects on antibiotic susceptibility. J Hosp Infect 2003;55:98-107.

26 Suller MTE, Russell AD: Antibiotic and biocide resistance in methicillin-resistant Staphylococcus aureus and vancomycin-resistant Enterococcus. J Hosp Infect 1999;43:281-291.
27 Dissemond J: Die Bedeutung des pH-Wertes für die Wunde. Hartmann Wundforum 2006; 1:15-19.

28 Ikeda T, Tazuke S, Watanabe M: Interaction of biologically active molecules with phospholipid membranes. I. Fluorescence depolarization studies on the effect of polymeric biocide bearing biguanide groups in the main chain Biochim Biophys Acta 1983;735:380-386.

29 Timofeeva L, Kleshcheva N: Antimicrobial polymers: mechanism of action, factors of activity, and applications. Appl Microbiol Biotechnol 2011;89:475-492.

30 Gesellschaft für Dermopharmazie e.V.: Wirkstoffdossiers für externe dermatologische Rezepturen, 2007.

31 Ratiopharm GmbH: Fachinformation PVPJod-ratiopharm ${ }^{\circledR}$ Salbe, 2008.

32 Reimer K, Wichelhaus TA, Schäfer V, Rudolph P, Kramer A, Wutzler P, Ganzer D, Fleischer W: Antimicrobial effectiveness of povidone-iodine and consequences for new applications. Dermatology 2002;204:114-120.

33 Mohammadi Z, Abbott PV: The properties and applications of chlorhexidine in endodontics. In Endodont J 2009;42:288-302. 